\title{
E-Learning Platform: A Sustainable Approach for Students' Learning during and after Coronavirus Pandemic in Oyo State Secondary Schools, Oyo State, Nigeria
}

\author{
Busuyi Francis Olowo ${ }^{1 *}$ (D)
}

${ }^{1}$ Obafemi Awolowo University, Ile-Ife, NIGERIA

*Corresponding Author: olowofrancis.of@gmail.com

Citation: Olowo, B. F. (2021). E-Learning Platform: A Sustainable Approach for Students' Learning during and after Coronavirus Pandemic in Oyo State Secondary Schools, Oyo State, Nigeria. European Journal of Interactive Multimedia and Education, 2(1), e02103. https://doi.org/10.30935/ejimed/9361

\begin{abstract}
E-learning approach cannot be underrated in sustaining teaching-learning activities in the schools. This paper reports a survey done that assessed the E-learning approach organized by organized by Oyo State government for Oyo State secondary school students. The study adopted quantitative approach of descriptive survey. The target populations of the study comprised only Senior Secondary School students in class three (SSS 3) within Oyo State Secondary Schools. The sample of 200 students was selected using simple random, purposive and convenience sampling techniques respectively. An instrument was used for the study. The data were analysed using frequencies, percentage scores, pie charts, mean and standard deviation (SD). The findings showed students were highly aware e-learning programmes (60\%) and highly participated during the programmes $(62.5 \%)$. The study equally indicated that e-learning programmes on radio and television organized by Oyo State government was very highly efficient (57\%). The study further indicated that inadequate power supply $(\mathrm{x}=3.45)$ and high cost of subscriptions to the satellite television stations $(\mathrm{x}=3.45)$ were factors hindering the students' participation during the E-learning programmes on radio and television. The study recommended that Government should continue the e-learning programmes during and after CONVID-19 might have fully eradicated and they should equally incorporate other electronic devise for teaching-learning activities such as Zoom, Google Classroom and social media.

Keywords: E-learning, students' learning' Coronavirus, Nigeria

Received: 10 Aug. $2020 \bullet$ Accepted: 12 Oct. 2020
\end{abstract}

\section{INTRODUCTION}

A new coronavirus became known in Wuhan, China on $31^{\text {st }}$ December, 2019 (Shrikrushna, Quazi, Shubham, Suraj, Shreya, Rohit, Suraj \& Biyani, 2020). This coronavirus pandemic is globally recognized as COVID-19. According to World Health Organisation (WHO) (2020), COVID-19 virus is a new virus that links to the same family of viruses as Severe Acute Respiratory Syndrome (SARS) and some types of common cold. It is a new disease caused by a novel strain of coronavirus. COVID-19 abbreviates as follow 'CO' stands for corona, 'VI' mean virus, while 'D' for disease and 19 represents 2019 (year discovered). This disease was formerly referred to as 2019 novel coronavirus (2019-nCoV). Meanwhile, Director General of the World Health Organization (WHO) declared the outbreak of this coronavirus disease on 30th January 2020 (Shrikrushna et al, 2020). On March 11, 2020, the World Health Organization (WHO) declared this disease a global pandemic. However, the emergency of COVID-19 had impacted negatively across the countries. The COVID-19 had caused many businesses to shut down temporarily, many people have lost their job and many people have died. As the death toll and number of infections significantly increased globally, the world began to panic. WHO advised on several methods such as hand washing, social distancing, and staying at home to prevent the spread of the virus and to save health systems across the world from a complete collapse (WHO, 2020). Governments across the world closed their border and also restrict the movement of the people but exempt the providers of essential services who are strictly observed social distance rules while providing necessary services as a way of curtailing the spread of the virus in each of the countries.

Surprisingly, the COVID-19 has greatly affected education sector. According to UNESCO (April 13 ${ }^{\text {th }}, 2020$ ) estimated 1.725 billion learners affected as a result of schools closure globally (representing about $99.9 \%$ of the world's student population). In Nigeria, Federal Government (FG) approved and ordered the closure of schools nationwide on March $19^{\text {th }}, 2020$ (Federal Ministry of Education (FME), 2020). The closure of schools resulted from persisting of confirmed cases since the inception of first case in February 27, 2020. The patient was an Italian citizen, who had recently arrived in Lagos from Europe and tested positive for the disease few days later. The COVID-19 pandemic has deprived over 80 million Nigeria learners access to quality education (Federal Ministry of Education (FME), 2020). However, the 
Table 1. Time table scheduled for Radio and Television Programmes in Oyo State for secondary schools students

\begin{tabular}{|c|c|c|c|c|}
\hline \multirow[b]{2}{*}{ DAY } & \multicolumn{2}{|c|}{ SUBJECTS } & \multicolumn{2}{|c|}{ SUBJECTS } \\
\hline & TIME & $\begin{array}{c}\text { MEDIUM OF } \\
\text { COMMUNICATION }\end{array}$ & TIME & $\begin{array}{c}\text { MEDIUM OF } \\
\text { COMMUNICATION }\end{array}$ \\
\hline \multirow{5}{*}{ MONDAY } & \multicolumn{2}{|c|}{ BIOLOGY } & \multicolumn{2}{|c|}{ ECONOMICS } \\
\hline & 9:15 - 9:45 A.M & OLUYOLE FM & 1:00 - 1:30 P.M & $\mathrm{BCOS}$ \\
\hline & $9: 30$ - 10:00 AM & AJILETE FM & 1:30 - 2:00 P.M. & OLUYOLE FM \\
\hline & 10:30 - 11:00 AM & OKE-OSUN FM & 2:30 - 3:00 P.M. & OKE OSUN FM \\
\hline & $12: 30-1: 00 \mathrm{PM}$ & $\mathrm{BCOS}$ & 4:00 - 4:30 P.M & AJILETE FM \\
\hline \multirow{5}{*}{ TUESDAY } & \multicolumn{2}{|c|}{ COMMERCE } & \multicolumn{2}{|c|}{ AGRIC SCIENCE } \\
\hline & 9:00 - 9:30 A.M. & $\mathrm{BCOS}$ & 1:30 - 2:00 P.M & OLUYOLE FM \\
\hline & 9:15 - 9:45 A.M & OLUYOLE FM & 2:30 - 3:00 P.M & OKE OSUN FM \\
\hline & 9:30 - 10:00 A.M. & AJILETE FM & 2:30 - 3:00 P.M. & AJILETE FM \\
\hline & 10:30 - 11:00 A.M. & OKE OSUN FM & 4:00 - 4:30 P.M & $\mathrm{BCOS}$ \\
\hline \multirow{5}{*}{ WEDNESDAY } & \multicolumn{2}{|c|}{ MATHEMATICS } & \multicolumn{2}{|c|}{ ENGLISH LANGUAGE } \\
\hline & 9:00 - 9:30 A.M. & $\mathrm{BCOS}$ & 1:30 - 2:00 P.M. & $\mathrm{BCOS}$ \\
\hline & 9:15 - 9:45 A.M & OLUYOLE FM & 1:30 - 2:00 P.M. & OLUYOLE FM \\
\hline & $11: 30$ - 12:00 PM & OKE OSUN FM & 2:30 - 3:00 P.M & OKE OSUN FM \\
\hline & $11: 30$ - 12:00 PM & AJILETE FM & 4:00 - 4:30 P.M. & AJILETE FM \\
\hline \multirow{5}{*}{ THURSDAY } & \multicolumn{2}{|c|}{ CHEMISTRY } & \multicolumn{2}{|c|}{ GOVERNMENT } \\
\hline & 9:00 - 9:30 A.M. & $\mathrm{BCOS}$ & 1:30 - 2:00 P.M. & OLUYOLE FM \\
\hline & 9:15 - 9:45 A.M & OLUYOLE FM & 2:30 - 3:00 P.M & BCOS \\
\hline & 10:30 - 11:00 A.M & OKE OSUN FM & 2:30 - 3:00 P.M. & OKE OSUN FM \\
\hline & 11:30 - 12:00 PM & AJILETE FM & 2:30 - 3:00 P.M. & AJILETE FM \\
\hline \multirow{5}{*}{ FRIDAY } & \multicolumn{2}{|c|}{ PHYSICS } & \multicolumn{2}{|c|}{ LIT IN ENGLISH } \\
\hline & 9:00 - 9:30 A.M. & $\mathrm{BCOS}$ & 1:30 - 2:00 P.M. & OLUYOLE FM \\
\hline & 9:15 - 9:45 A.M & OLUYOLE FM & 2:30 - 3:00 P.M & OKE OSUN FM \\
\hline & 10:30 - 11:00 A.M. & OKE OSUN FM & 2:30 - 3:00 P.M. & AJILETE FM \\
\hline & 11:30 - 12:00 PM & AJILETE FM & 4:30 - 5:00 P.M. & BCOS \\
\hline
\end{tabular}

Source: Federal Ministry of Education (FME, 2020)

early closure of schools has safeguarded more lives of learners, teachers, education personnel and the wider community. In response to school closures, UNESCO (2020) recommended distance learning programs and open educational applications and platforms for schools and teachers to reach learners as a way to limit disruption of education.

Federal government and State governments of Nigeria embraced and encouraged e-learning programmes as method of engaging students during the week to bridging the gap of schools closure. These e-learning programmes were in different dimensions but the most widely approach adopted by most of states was through Radio and Television programs. Radio learning approach is the method that allows students to have access to voices communication method of teaching. Whereby, television learning approach is the approach that allows students to have access to audio and video information of teaching. This method allows students to see and hear from the teacher or tutor while the class is going on television. This study focused on elearning method adopted by Oyo State government for secondary school students in the state.

Oyo State is one of the states in Nigeria that participated in both the Radio and Television programs. On April 1st, 2020, Oyo State government commenced school on Air-Video and radio broadcasting for secondary school students in the state (educeleb.com). The programs were accessible on Radio and Television Channels of the
Broadcasting Corporation of Oyo State (BCOS). The time table of the programmes was compiled by Federal Ministry of Education for all states in the country. Table 1 shows details of the time table for secondary school students in Oyo State.

News Agency of Nigeria (NAN) visited secondary schools in Ibadan, the Oyo State capital on July 6, 2020 which was the date announced by Oyo State government for the graduating classes to resume in preparation for their final year examination (West Africa Examination Council and National Examination Council). According to their report, some senior secondary school students within Ibadan metropolis were aware and participated in government learning programme organised on television and radio (NAN, 2020). The above attestation statements from the students affirmed that the programs were done for Oyo State secondary school students. However, the report was focused only on state capital, that is, Ibadan metropolis while other local government areas were neglected. The study earlier investigated by Olumorin, Aderoju and Onojah (2018) on students' awareness and utilization of educational broadcasts to learn in Ogbomoso, Oyo State Nigeria indicated that students were not aware of the educational radio and television programs even though the students have access to the programmes. The study of Olumorin et al. (2018) made it clear that the students were not aware of the radio and television programs organized in Ogbomoso despite that the programme were accessible to them. During the COVID-19 pandemic 
the government organized such programme to the student to bridge the gap of schools closure. There was insinuation if the students really aware and participated as expected. This calls for research investigation.

The objectives of the study were to:

a) examine the level of awareness of students on the e-learning programmes organized by Oyo State government

b) investigate the level of students' participation on the e-learning programmes organized by Oyo State government

c) examine the level of efficiency of the e-learning programmes by Oyo State government

d) examine the factors hindering the students awareness and participation in the E-learning programmes by Oyo State government

The following research questions were raised to guide the study:

1. What is the level of awareness of students on the e-learning programmes organized by Oyo State government?

2. What is the level of students' participation on the e-learning programmes organized by Oyo State government?

3. What is the level of efficiency of the e-learning programmes by Oyo State government for Secondary school Students?

4. What are the factors hindering the students' awareness and participation in the e-learning programmes organized by Oyo State government?

\section{LITERATURE REVIEW}

E-learning is regarded as innovative and modern method of teaching. It was implemented into education globally because it promotes the accessibility to Internet. Thiele (2003) referred e-learning as educational system whereby the teacher and the students are physical separated but link together through the means of technology tool that connect the teaching-leaning activities. Koohang and Harman (2005) defined e-learning as means of using various electronic medium as a way of delivering activities relevant to instructing, teaching, and learning. In same view, Koohang and Harman (2005) regarded electronic medium as video/audio tape, internet, satellite TV, extranets, intranets, and CD ROM. In line with the definition, Mayer, and Ruth (2011) regarded e-learning as instruction delivery method using digital device such as a mobile device and computer to facilitate and support teaching-learning activities. From above definitions, e-learning simply means distance learning method that connects teacher and students together without physical present. This means that various electronic gadget may connect teaching-learning activities together such as radio and television.

According to Hasanzadeh (2002), e-learning has increased learning up to $20 \%$ to $30 \%$ while compared with traditional classrooms. This is an indication that e-learning cannot be underrated and it promotes learning of students. Fredericksen, Pickett, Pelz, Swan, and Shea (2007) reported that $94 \%$ of distance learners who completed their training courses believed that they have learnt more compared to traditional classes. Thiele (2003) conducted study on students' learning and elearning method. The study found out that the extent of learning using electronic method was more than the traditional system of learning. He further acknowledged that learners that use electronic methods will have access to more information. In line with the statement, empirical findings of Demuyakor (2020) suggested that the implementation of online learning programs was a very great idea. Therefore, it is the fact e-leaning contributes to teaching-learning activities. Nigeria government incorporated e-leaning (radio and television programmes) approach of teaching to substitute traditional approach. The programmes were purposely organized to bridge the gap of schools closure as a result of convid-19 pandemic.

According to Omiko (2016), television and radio are powerful sources of learning that leads to effective. Empirical study carried out by Omiko (2018) indicated that majority of the children were familiar with radio and television programmes. The study further disclosed that large number of the children learned skills set out to inculcate from the programmes. This implies that radio and television are acceptable for students to learn. However, the study of Ogbole (2019) traced some of the challenges facing the students to lack of access to radio sets, ignorance of the benefits inherent in radio educational programmes and non-inclusion of these programmes in schools lesson plans. Though, the above studies were investigated before COVID-19. Moreover, study of Dominic, Ibrahim, Kareem, and Chukwuemeka (2020) focused on impact of COVID-19 pandemic on people with disabilities and its implications on special education practice in Nigeria. In the same line, Dominic, Ibrahim, Kareem and Chukwuemeka (2020) assessed whether Ghanaian international students in China are satisfied with the "mass" online learning in higher educational institutions in Beijing, China. However, little or no study focused on e-learning approach organized for Oyo State secondary school students during the COVID-19 pandemic specifically in Oyo State, Nigeria.

\section{METHODS}

\section{Research Design}

The study adopted quantitative approach of descriptive survey. The design was appropriate because the subjects were studied as they were in the natural environment without any manipulation or active effort to control them. Meanwhile, researcher collected data, analysed and made final report of the subject the way they were in the study location.

Population of the Study

The population comprised 2,773,418 students in all 969 public secondary schools in Oyo State (FME, 2006). The target populations of the study comprised only Senior Secondary School in class three (SSS 3) students within Oyo State.

\section{Sample and Sampling Techniques}

The sample comprised total number of 240 students. Simple random sampling technique was used to select one Local Government Area (L.G.A) from each of the three senatorial districts to make total of three Local Government Areas (L.G.As). From each L.G.A, 3 secondary schools were selected making total of 12 schools. A purposive sampling technique was used to select the graduating students (SS 3). Purposive sampling techniques was used because the graduating students of secondary schools were preparing for their Senior Secondary School Certificate Examination (West Africa Examination Council and National Examination Council) as at the time of investigation. Likewise, they have temporarily resumed to schools in preparation their examination. From each secondary school, 20 students were selected using convenience sampling technique that made total sample to be 240 students. Convenience sampling was used as a result of 
Federal Government regulation (lockdown and social distance) during the COVID-19 pandemic.

\section{Instrument for Data Collection}

A self-structured questionnaire title; Assessment of E-learning Programmes organized by Oyo State Government for Students of Secondary Schools (AEPOSGSSQ) was used to gather information. AEPOSGSSQ was divided into section A, B, C, D and E. Section A contains 2 items on social demographic characteristics of respondents; section B contains 5 items on level of awareness of students on the Elearning programmes, section $\mathrm{C}$ contains 5 items on level of students' participation on the E-learning programmes, Section D contains 5 items on level of efficiency of the E-learning programmes and section $\mathrm{E}$ contains 5 items on factors hindering the students awareness and participation in the E-learning programmes. For AEPOSGSSQ, 4-point Likert type scale of Strongly Agree $(\mathrm{SA})=4$, Agree $(\mathrm{A})=3$, Disagree $(D)=2$ and Strongly Disagree $(S D=1$ were used for section B to E. In section E, Strongly Agree $(S A)=4$, Agree $(A)=3$, Disagree $(D)=2$ and Strongly Disagree $(S D)=1$ were added together (that is, $4+3+2+1=10 / 4$ $=2.50$ ) to determine the cut-off point of 2.50. Any mean scores that was 2.50 and above was considered as Agree while a mean score that was below 2.50 was considered as Disagree in the study.

\section{Validity of the Instrument}

The researcher with the aids of related literature designed a questionnaire for the study. The questionnaire covered all the research questions of the study. Content of the questionnaire was corrected and well scrutinized by the experts in Department of Educational Management, Faculty of Education, Obafemi Awolowo University, Ile - Ife, Nigeria in order to ensure that it measure what was design for to measure.

\section{Reliability of the Instrument}

Test re-test method was used to determine the reliability of the study. Pilot study was done by administering the questionnaire to 20 respondents which were not parts of the study but having similar characteristics at interval of 14 days. The data collected was coded and analyzed using the Pearson Moment Correlation Coefficient. A value of reliability co-efficient of 0.859 was obtained which was considered adequate for the study. The respondents used for the reliability was excluded from the study sample.

Table 2. Reliability Test Results

\begin{tabular}{cccc}
\hline Sections & No of Items & Reliability Index & Status \\
\hline B & 5 & .823 & Reliable \\
\hline C & 5 & .847 & Reliable \\
\hline D & 5 & .892 & Reliable \\
\hline E & 5 & .873 & Reliable \\
\hline Scale of Reliability & $\mathbf{2 0}$ & $\mathbf{. 8 5 9}$ & Reliable \\
\hline
\end{tabular}

Source: Field Work, 2020

\section{Data Collections Techniques}

Permission was granted by each of the principals in the sampled schools to administer questionnaires to the students. The researcher administered the instrument within two weeks. The questionnaire was handed over to individual students of the sampled schools. The researcher gave understanding explanation of the questionnaire to the students. He also emphasized the purpose and important of their responses. He further assured the students that their responses would be kept confidential and only be used for the purpose of this research.
Table 3. Participants' Demographic Data

\begin{tabular}{cccc}
\hline Variable & Categories & \multicolumn{2}{c}{ Students } \\
\hline & & Frequency & Percent (\%) \\
\hline \multirow{3}{*}{ Gender } & Male & 113 & 56.5 \\
\cline { 2 - 4 } & Female & 87 & 43.5 \\
\cline { 2 - 4 } & Total & $\mathbf{2 0 0}$ & $\mathbf{1 0 0}$ \\
\hline
\end{tabular}

Some students reacted to the questionnaire immediately while some were collected back later of the day. Out of 240 questionnaires distributed to students, only 200 were able to retrieve from the students, that is, $83.33 \%$.

\section{Data Analysis Techniques}

Data collected were analyzed using descriptive statistics approach. Frequencies, percentage scores and pie charts were used to interpret research questions 1-3 while mean and standard deviation (SD) were used to answer the research questions 4 . The interpretation of the mean scores was based on cut-off point of 2.50, the basis for arriving at 2.50 was by adding $4+3+2+1=10 / 4=2.50$. Any mean scores that was 2.50 and above was considered Agree while a mean score that was below 2.50 was considered Disagree in the study. Statistical Packages for the Social Science (SPSS) was the tool that used to analyze the data.

\section{RESULTS AND DISCUSSION OF FINDINGS}

As shown on Table 3, 56.5\% of the students were male while $43.5 \%$ of the students were female, this means that majority of the students were male.

Research Question 1: What is the level of awareness of students on the e-learning programmes organized by Oyo State government?

Table 4 and Figure 1 depict the level of awareness of students on 3the e-learning programmes organized by Oyo State government. As shown on the table, $7 \%$ of the students concurred that they were very highly aware of the e-learning programmes on radio and television organized by Oyo State government. Again, $60 \%$ of the students affirmed that they were highly aware of the e-learning programmes. Meanwhile, $13 \%$ of the students claimed to be moderately aware. It was claimed by $7.5 \%$ of the students that they were fairly aware of the elearning programme. However, $12.5 \%$ of the students made it clear that they were not aware of the e-learning programmes on radio and television. The high percentage of the students confirmed that they were highly aware, it can be suggested in the study that high number of students were well aware of the e-learning programmes on radio and television that was organized by Oyo State government to facilitate the learning of the students during the closure of schools as a result of pandemic. This implies that the students were aware of the programmes through their parents, friends, newspaper, social media and Radio/Television news. Though, government still needs to circulate information to parents and guardian most especially in the rural area so that they can have more information to pass across their children about the educative programmes organized on radio and televisions. The finding concurred with the findings of Akhter (2011) who reported that students in Pakistan showed mass awareness of educational television programmes (ETV) for effective distance learning. This study equally agreed with the study of Omiko (2018) who reported that majority of the children were familiar with radio and television programmes. However, the findings of the study contradicted 
Table 4. Level of awareness of students on the e-learning programmes organized by Oyo State government

\begin{tabular}{|c|c|c|c|}
\hline \multicolumn{2}{|c|}{ Level of Students' Awareness } & \multirow{2}{*}{$\begin{array}{c}\text { Frequency } \\
14\end{array}$} & \multirow{2}{*}{$\begin{array}{c}\text { Percentages } \\
7\end{array}$} \\
\hline Very Highly Aware & $(75>)$ & & \\
\hline Highly Aware & $(60-74)$ & 120 & 60 \\
\hline Moderate Aware & $(45-59)$ & 26 & 13 \\
\hline Fairly Aware & $(30-45)$ & 15 & 7.5 \\
\hline Not Aware & $(<29)$ & 25 & 12.5 \\
\hline Total & & 200 & 100 \\
\hline
\end{tabular}

Field work, 2020

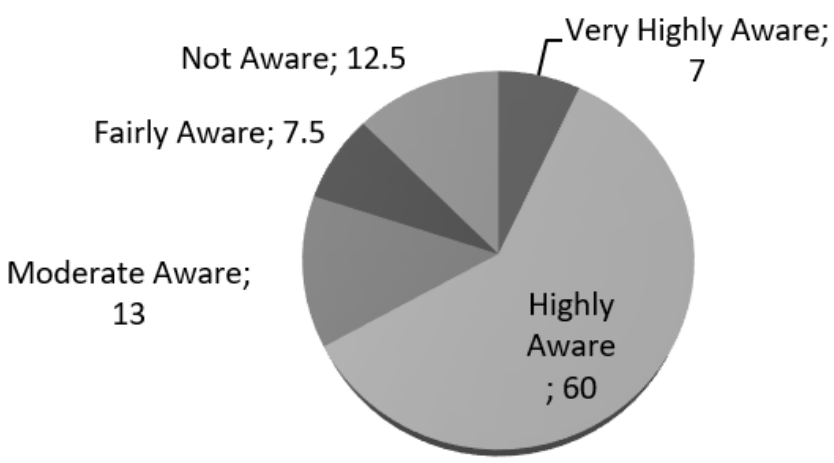

Figure 1. Pie Chart Showing level of awareness of students on the elearning programmes organized by Oyo State government

the study of Olumorin, Aderoju and Onojah (2018) who reported that students were not aware of the educational radio and television programs.

Research Question 2: What is the level of students' participation on the e-learning programmes organized by Oyo State government?

Table 5 and Figure 2 show the level of students' participation on the e-learning programmes organized by Oyo State government. As shown on the table, $6.5 \%$ of the students claimed that they were very highly participated in e-learning programmes on radio and television organized by Oyo State government. It was also affirmed by $62.5 \%$ of the students that they were highly participated during the e-learning programmes. As shown on the table, $13.5 \%$ of the students were moderately participated during the programmes. It was disclosed by $7.5 \%$ of the students that they were fairly participated during the programme. However, $10 \%$ of the students claimed that they were not participated at all during the programmes. Having looking at high percentage of the students affirmed to be highly participated during the radio and television programmes, it denotes that high number of students in the study area were highly participated during the elearning programmes on radio and television that organized by Oyo State government. This implies that students have much time to participate, paid much attention and really enjoyed the programmes. The high level of participation might be because the students were fully at home which allowed them to have enough time to participate. It might also be because the students still have final examination ahead that needs proper preparation. The study was in consonance with the study of Familusi and Owoeye (2014) who claimed in their study that the residents of Ado- Ekiti, Ekiti-State have good access to radio and television sets for receiving programmes. The study was also concurred with the study of Olumorin, Aderoju and Onojah (2018) who affirmed that students have access to participate in radio and television programmes.
Table 5. Level of students' participation on the e-learning programmes organized by Oyo State government

\begin{tabular}{ccc}
\hline Level of Students' Participation & Frequency & Percentages \\
\hline Very Highly Participated $(75>)$ & 13 & 6.5 \\
\hline Highly Participated $(60-74)$ & 125 & 62.5 \\
\hline Moderately Participated $(45-59)$ & 27 & 13.5 \\
\hline Fairly Participated $(30-45)$ & 15 & 7.5 \\
\hline Not Participated $(<29)$ & 20 & 10 \\
\hline Total & $\mathbf{2 0 0}$ & $\mathbf{1 0 0}$ \\
\hline
\end{tabular}

Field work, 2020

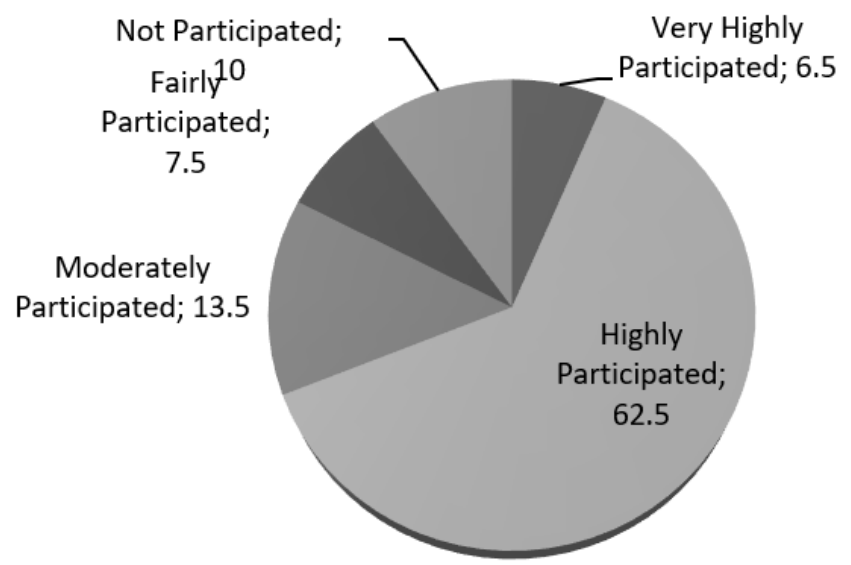

Figure 2. Pie Chart Showing level of students' participation on the elearning programmes organized by Oyo State government

Research Question 3: What is the level of efficiency of the elearning programmes organized by Oyo State government for Secondary school Students?

Table 6 and Figure 3 show the level of efficiency of the E-learning programmes organized by Oyo State government for Secondary school Students. According to the table, $57 \%$ of the students claimed that elearning programmes on radio and television organized by Oyo State government was very highly efficient. Also $25 \%$ of the students were with the opinion that the programmes were highly efficient. It was also affirmed by the $14 \%$ of the students that the programmes were moderately efficient. Equally, $2.5 \%$ of the students were in opinion that the programmes were fairly efficient. Contrarily, $1 \%$ of the students disclosed that e-learning programmes on radio and television was not efficient. The percentage of students claiming that the programmes were very highly efficient were high, it suggested that the e-learning programmes on radio and television organized by Oyo State government for Oyo State secondary school students was timely, held as scheduled and consistent during the schools closure. Meanwhile, it could mean that Oyo State government is very passionate and persistence to ensure that the students learn during the closure of the schools. 
Table 6. Level of efficiency of the e-learning programmes organized by Oyo State government for Secondary school Students

\begin{tabular}{cccc}
\hline $\begin{array}{c}\text { Level of E-learning Programme' } \\
\text { Efficiency }\end{array}$ & Frequency & Percentages \\
\hline Very Highly Efficient & $(75>)$ & 115 & 57.5 \\
\hline Highly Efficient & $(60-74)$ & 50 & 25 \\
\hline Moderately Efficient & $(45-59)$ & 28 & 14 \\
\hline Fairly Efficient & $(30-45)$ & 5 & 2.5 \\
\hline Not Efficient & $(<29)$ & 2 & 1 \\
\hline Total & & $\mathbf{2 0 0}$ & $\mathbf{1 0 0}$ \\
\hline
\end{tabular}

Field work, 2020

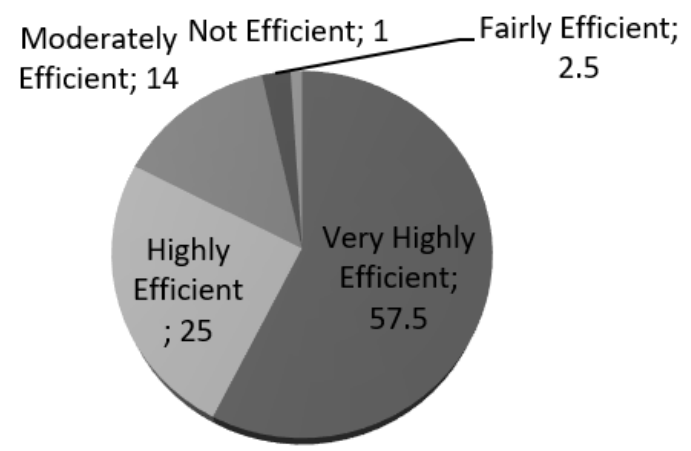

Figure 3. Pie Chart Showing level of efficiency of the e-learning programmes organized by Oyo State government for Secondary school Students

Research Question 4: What are the factors hindering the students' awareness and participation in the e-learning programmes by Oyo State government?

As shown in Table 7, items 4 and 5 had mean rating scores above the criterion level. The mean ratings were above the criterion level of 2.50 set for accepting items. This implies that students agreed that inadequate power supply and high cost of subscriptions to the satellite television stations were the factors hindering their awareness and participation during the e-learning programmes organized by Oyo State government. However, item 1, 2, and 3 had mean rating scores below the criterion level. The mean ratings were below the criterion level of 2.50 set for accepting items. This implies that students disregarded 1,2, and 3 items as factors hindering their awareness and participation during the e-learning programmes organized by Oyo State government. Therefore, it could be suggested that inadequate power supply and high cost of subscriptions to the satellite television stations were major factors hindering the students' participation during the e-learning programmes organized by Oyo State government. It therefore suggested that electricity should be properly supplied and parents should endeavor to subscript to their satellite television stations so that the students would be able to participate in all the programmes. The study concurred with the study of Familusi and Owoeye (2014) who reported that the cost of accessing information on radio and television were not expensive but paying subscription to DSTV and other cable television was more expensive. Moreover, the study is in line with the findings of Olumorin, Aderoju and Onojah (2018) who claimed that inadequate of power supply and high cost of subscriptions to the satellite television stations to access educational broadcast were considered as the most prominent mitigating factor.

\section{CONCLUSION}

E-learning approach cannot be over-emphasized among the teachers and students in the secondary schools most especially during this COVID-19 pandemic. Meanwhile, e-learning approach of learning has been recognized as modern tool that can facilitate teaching-learning activities. This study showed that the students in the study area were aware and participated during the radio and television progrmames. The study further indicated that the programme was consistent, timely and held as scheduled. However, challenges facing the students to participate adequately were inadequate power supply and high cost of subscriptions to the satellite television stations. Meanwhile, it is imperative and crucial for the governments, parents, communities, administrators, teachers and students to see e-learning approach as a platform that can improve and enhance teaching-learning activities. The government of Oyo State should continue with the e-learning programme organised for the secondary school students in the state. Therefore, the researcher advocates that governments, parents, communities, administrators, and teachers in Nigeria should encourage and allow e-learning approach such as radio and television for teachinglearning activities. The approach will support the physical classroom teaching.

\section{RECOMMENDATIONS}

Base on the findings of the study, the following recommendations were made:

1. Government should continue with the e-learning programmes during and after the COVID-19 might have fully eradicated

2. Government should also incorporate other electronic devise for teaching learning activities such as Zoom, Google Classroom and social media

3. School principal should collaborate with their teachers to create social media platform such as WhatsApp, Facebook, Twitter, and Telegram where the students can have access to assignment and other material needed for their studies.

4. Parents and community should support the effort of the government by providing conducive environment and material for their children to participate during the e-learning programmes organized by government.

Table 7. Time table scheduled for Radio and Television Programmes in Oyo State for secondary schools students

\begin{tabular}{cccccc}
\hline S/N & ITEMS & N & Mean & SD & Decision \\
\hline 1 & Unaware of time schedule for the programmes & 200 & 2.14 & 1.037 & Disagree \\
\hline 2 & The programs are not interesting and encouraging to participate & 200 & 2.83 & 0.984 & Disagree \\
\hline 3 & High cost to purchase television and radio sets & 200 & 2.30 & 0.926 & Disagree \\
\hline 4 & High cost of subscriptions to the satellite television stations & 200 & 3.30 & 0.926 & Agree \\
\hline 5 & Inadequate power supply to aware and participate & 200 & 3.45 & .0812 & Agree \\
\hline
\end{tabular}


5. Students should also show more interest to e-learning activities organized. They should also endeavor to learn computer and other internet device so that they can have much knowledge of how to use e-learning devices.

6. Stable electricity should be supplied in the state and parents should provide alternative power supply incase when general electricity is off.

\section{REFERENCES}

Akhter, N. (2011). Evaluation of educational television programmes for distance learning. The Turkish Online Journal of Educational Technology, 10(4), 188-194.

Demuyakor, J. (2020). Coronavirus (COVID-19) and online learning in higher institutions of education: A survey of the perceptions of Ghanaian international students in China. Online Journal of Communication and Media Technologies, 10(3), e202018. https://doi.org/10.29333/ojcmt/8286

Dominic, S., Ibrahim, A. M., Kareem, M. A., \& Chukwuemeka, E. J. (2020). Impact of Covid-19 pandemic on people with disabilities and its implications on special education practice in Nigeria. International Journal of Innovative Science and Research Technology (IJISRT), 5(6), 803-808.

Familusi, E. B., \& Owoeye, P. O. (2014). An assessment of the use of radio and other means of information dissemination by the residents of Ado- Ekiti, Ekiti-State, Nigeria. Library Philosophy and Practice (e-journal), 1-29. Retrieved July 14, 2020, from http://digitalcommons.unl.edu/libphilprac/1088

Federal Ministry of Education (FME, 2020). Compilation by FME NEMIS on the status of state government and FCT interventions on the implementation of digital learning during lockdown. Elearning Resources: Abuja.

Fredericksen, E., Pickett, A., Pelz, W., Swan, K., \& Shea, P. (2007). Student satisfaction and perceived learning with online coursesprinciples and examples from the SUNY Learning Network. (cited 2007 Jun 25). Retrieved from http://www.sloan.org/conference/ proceedings/1999summer/papers/99summer_fredericksen2.pdf
Hasanzadeh, M. (2002). Electronic learning. Tehran: Tadbir Publication (Persian).

Koohang, A., \& Harman, K. (2005). Open source: A metaphor for elearning. Informing Science. The International Journal of an Emerging Transdiscipline, 8, 75-86. https://doi.org/10.28945/488

Mayer, E. R., \& Ruth, C. C. (2011). E-Learning and the Science of Instruction: Proven Guidelines for Consumers. USA: Pfeiffer Publishers, San Francisco.

News Agency of Nigeria (2020). Students in graduating classes resume in Oyo. Pulse Nigeria.

Ogbole, J. (2019). Uses and gratifications of radio educational programmes by senior secondary school students in Northeast geo-political region, Nigeria (Unpublished Ph. D Thesis), Benue State University, Makurdi

Olumorin, C. O., Aderoju, M. A., \& Onojah, A. O. (2018). Students awareness and utilization of educational broadcasts to learn in Ogbomoso, Oyo State Nigeria. Turkish Online Journal of Distance Education (TOJDE), 19(3), 182-192. https://doi.org/10.17718/ tojde. 445122

Omiko, A. (2016). Using computer instruction (Unpublished Lecture Note). Department of Science Education, Ebonyi State University, Abakaliki.

Omiko, A. (2018). A Effect of Children's Radio/Television Programmes on Basic Science and Technology Education. International Journal of Science Research and Education, 5(3), 6254-626.

Thiele J. E. (2003). Learning patterns of online students. Journal of Nursing Education, 42(8), 364-366. https://doi.org/10.3928/01484834-20030801-08

UNESCO (2020). COVID-19 Educational Disruption and Response. Retrieved from https://en.unesco.org/covid19/educationresponse

UNESCO (4 March, 2020). 290 million students out of school due to COVID19: UNESCO releases first global numbers and mobilizes response. Retrieved on 6 July 2020 from https://en.unesco.org/news

World Health Organization, (2020). Q \& A on Coronaviruses, (COVID-19). Retrieved from https://www.who.int/news$\mathrm{room} / \mathrm{q}$-a-detail/q-a-coronaviruses 